\title{
THE EDGE OF UTILITY: SLAVES AND SMALLPOX IN THE EARLY EIGHTEENTH CENTURY
}

by

\section{LARRY STEWART*}

The outbreak of plague at Marseilles in 1719 caused British authorities great alarm. French efforts to check the spread of the disease were uncertain of success and there was concern that commercial connexions might provide a means by which the dreaded disease could again bring devastation as in the seventeenth century. The terror plague provoked, however, might equally have been directed toward the smallpox epidemics that were occurring with increasing frequency. But there, too, the realization that commerce might be commensurate with contagion was part of a complicated fabric of disease, political factors, religious sensibilities about divine providence, and the defence of profits in an economic climate that was proving difficult for many of the established chartered companies. Thus the Bubble Act of 1720 that tried to prevent a recurrence of the innumerable frauds which had haunted traders and aristocrats alike, and the Quarantine Act of 1721 that endeavoured to control the spread of plague both represented a deliberate act of government intervention. Quarantine is by definition an act of authority, and in the early eighteenth century it explicitly altered the conditions of trade. In a much wider sense, before 1750 there appears to have developed an incipient notion of public health that had the potential to transform trade as well as the conditions of mortal and disfiguring diseases. And in a world terrified by plague, in which smallpox stalked aristocratic families and the slaves of the African Company alike, it fell to the learned Fellows of the Royal Society to form the critical if sometimes tenuous association between the world of traders and politicians.

PUBLIC HEALTH AND PUBLIC POLICY IN THE EARLY EIGHTEENTH CENTURY

In the aftermath of the South Sea Bubble of 1720, the righteous may have found justice in the misery of it all. To some, the collapse of stocks probably seemed like a visitation upon the avaricious and atheistical who had forsaken the church for a flood of paper fortunes. As with the Restoration, whose Puritan opponents saw the plague of 1665 as divine retribution, Jacobites watched as the Hanoverian succession was undermined by fortunes lost in a dismal spiral into poverty. And to the Scottish surgeon James Houstoun, who came to London in search of a patron, the rage of stock-jobbing had been contagious, a "golden Phrenzy ... [which] first broke out in France, and so contaminated the Air, that it wafted itself over into Britain, and even

${ }^{*}$ Larry Stewart, PhD, Department of History, University of Saskatchewan, Saskatoon, Canada S7N owo. 


\section{The edge of utility}

returned back and infected the Dutch". ${ }^{1}$

Financial ruin was only one element of a terrible trinity of debt, disease, and Jacobite spies which haunted the ministry of Robert Walpole. His administration, besieged on both sides by Stuart plots and by holders of worthless stock in innumerable, often mad, schemes, was now faced with an outbreak of plague on the Continent. It consulted the most prominent society physicians in order to prevent a recurrence of the disease which had decimated Restoration England. The plague that raged throughout France in 1719 and 1720, the horrors of which were reported in the English press, came at a difficult time for the Walpole Whigs. Jacobite invasions were a constant fear. Yet disease also lurked along the trade routes from the Mediterranean to the Caribbean. While Jacobites and plague both required constant vigilance-and their origins were both French-epidemics at least seemed controllable by harsh measures.

The Quarantine Act that came into effect in February 1721, had been designed largely on the advice of the prominent physicians and Fellows of the Royal Society, Richard Mead, John Arbuthnot, and Hans Sloane. ${ }^{2}$ And the effort to throw up a quarantine around England to prevent the importation of the disease made the London merchants especially nervous amid the general decline of stocks. Nonetheless, opposition came from quarters whose motivation cannot simply be accounted for by the defence of trade. There can be no question that the debates in Parliament were mixed in some measure with a search for political advantage and a little of the public hysteria. Francis Atterbury, the high-flying Bishop of Rochester, gave vent to his Tory spleen when he compared the South Sea Company and its directors to the pestilence of southern Europe. If Atterbury's opposition to the ministry was more a reality in London than the plague turned out to be, the High-Church Tory opposition was soon swelled by the alarm of the London merchants. ${ }^{3}$ But the ministry was not alone in the pamphlet wars that followed. Edmund Gibson, Bishop of London, and Walpole's ecclesiastical lieutenant, took up the cause against the "Art and Knavery of others" who misread the danger of an epidemic and the motives of the government. ${ }^{4}$ But there were those who saw in the Quarantine Act and the measures used to enforce it the growth of despotic government. Hans Sloane received a plaintive letter from a woman who signed herself simply "Belinda": . . . "was there ever any sorrow like our sorrows almost ruined by South Sea while none but court parisites bribed senators who have

\footnotetext{
${ }^{1}$ James Houstoun, Memoirs of the life and times of James Houstoun, M.D. (formerly physician and Surgeon-General to the Royal African Company's settlements in Africa, and late surgeon to the Royal Asiento Company's factories in America), London, 1747, p. 112.

${ }^{2}$ Alfred James Henderson, London and the national government, 1721-1742. A study of City politics in the Walpole administration, Durham, University of North Carolina Press, 1945, pp. 33ff. See also, Charles F. Mullett, 'The English plague scare of 1720-23', Osiris, 1936, 11: 487-491; and R. Oratz, 'The plague. Changing notions of contagion: London 1665-Marseilles 1720', Synthesis, 1977, 4: 4-27.

${ }^{3}$ Although Atterbury did not publicly blame the Ministry, he did not have to. Others were happy to do the work. Mead later reported that Atterbury admitted the intentions of the Quarantine Act were good although the opposition used it as a club to bludgeon the government with charges of despotism. See Henderson, op. cit., note 2 above, p. 40, n.80; and G.V. Bennett, The Tory crisis in church and state, 1688-1730. The career of Francis Atterbury, Bishop of Rochester, Oxford University Press, 1975, p. 226.

'Edmund Gibson, The causes of the discontents, in relation to the plague, and the provisions against it, fairly stated and consider'd, London, 1722, cited in Mullett, op. cit., note 2 above, pp. 491-492.
} 


\section{Stewart}

plunderd the nation are able to live \& to complet the missery by the advice of Mead \& that Scotch quack [Arbuthnot?] wee are to be shutt up in pest hoves garded by souldeirs \& hired watchmen who shall swere the plauge is one us tho it be but a common feavor as it is in france-what else can be expected from such an act of parliment but death \& misery. ..."5

Such lamentations may be extreme but they may also reflect a growing fear of the stringent penalties-such as death without benefit of clergy, which was to result from violation of the law. ${ }^{6}$ Pesthouses as prisons for the sick and quarantine, which threatened to cut off commerce, completed the demonology of the Robinocracy. It was precisely for this reason that Edmund Gibson sought to answer the impressions created by "disaffected or designing Men". He was particularly agitated by the criticism that quarantine was a French measure, especially when advanced by those Jacobite sympathizers who would "have brought upon us a much sorer Plague than what we now fear, I mean, the utter Destruction of our Religion and Liberties".? Politics and public health were not matters given to easy separation.

If the South Sea Bubble and quarantine precipitated a crisis of confidence, diseases-especially smallpox-held the eighteenth-century public frozen in perverse fascination and often bewilderment. Even the physicians themselves were soon embroiled in a major controversy over how to deal with a recurrent and virulent form of smallpox which had reached the stage of a pandemic. So, in the disputes about radical intervention by inoculation it was no surprise that opponents should note the connexions: "We have seen South-Sea Schemes, good Parliaments, Bills for preventing the Plague; heard of Plots; but, till now, never dreamt that Mankind would industriously plot to their own Ruin, and barter Health for Diseases". 8 The rhetoric in such pronouncements only masked the fear that touched the minds of those who felt their world had collapsed-for financial, political, or religious reasons. Nevertheless, the threat of plague and smallpox was quite real. ${ }^{9}$ Even allowing a degree of metaphorical licence, in the late summer of 1719 reports circulated about smallpox raging between Acton and Harrow on the Hill and "a sad Outcry rais'd (especially by ancient Females) of a Plague, Pestilence, and what not, which has occasion'd abundance to leave the Town...".10 A week later, a conference of London physicians sought to reassure the population of the relative health of London

\footnotetext{
${ }^{5}$ British Library [BL], Sloane MSS 4046, fols. 173-174, 5 January 1721[/2].

${ }^{6}$ Henderson, op. cit., note 2 above, p. 45.

${ }^{7}$ Gibson, op. cit., note 4 above, 1721 ed., pp. 4, 8. Twenty-five years later, Richard Mead argued that reason alone had demanded strict enforcement, as even the natives of the Cape of Good Hope had proved prepared to accept. Richard Mead, $A$ treatise on the small pox and measles, London, 1747, pp. 7-8. See also, Richard Elphick, Kraal and castle, New Haven, Conn., Yale University Press, 1977, pp. 231-234.

${ }^{8}$ Legard Sparham, Reasons against the practice of inoculating the small pox as also a brief account of the operation of this poison, in fused after this manner into a wound, London, 1722, p. 26; quoted in Genevieve Miller, The adoption of inoculation for smallpox in England and France, Philadelphia, University of Pennsylvania Press, 1957, p. 103.

${ }^{9}$ It has been suggested that the Marseilles plague may have been a virulent form of smallpox. John Carswell, The south sea bubble, London, Cresset Press, 1961, pp. 173, 200-201. Cf. Andrew B. Appleby, 'Nutrition and disease: the case of London, 1550-1750', J. interdiscip. Hist., 1975, 6: 7; and Charles Creighton, $\boldsymbol{A}$ history of epidemics in Britain, 2 nd ed., ed. by D.E.C. Eversley, E. Ashworth Underwood, and Linda Ovenall, London, Cass, 1965, vol.2, passim.

${ }^{10}$ Original Weekly Journal, 22 August 1719, p. 1514.
} 
"notwithstanding the great Numbers of young People which are daily carried off by Fevers"..11

\section{SMALLPOX AND THE INOCULATION DEBATE}

If quarantine against plague raised the spectre of despotism, then the alternative methods of dealing with epidemics of smallpox raised a furious and prolonged controversy that lasted well into the eighteenth century. The efforts, largely by members of the Royal Society, to encourage the introduction of inoculation produced a bitter debate in medical and in religious circles. Here too, the medical innovators were attacked not only by the doubtful physicians and surgeons unconvinced by the increasing weight of evidence but also by representatives of the High Church like Edmund Massey, lecturer of St Alban, Wood Street, in a sermon on "the Dangerous and Sinful Practice of Inoculation". ${ }^{12}$ For some, the issue of inoculation was not simply one of public health but of endangering the lives of children, perhaps spreading the disease. Equally serious was the question of the lawfulness of the process, "being deemed a tempting of God's providence, and therefore a heinous crime". ${ }^{13}$ The issue was a moral one and as such the response of the empirics was as unconvincing as it was wide of the mark. That may be one reason why, despite the apparent preponderance of favourable commentary from the Royal Society, the dispute festered for decades.

Of course, the physicians of the Royal Society did not let the challenge rest. Dr John Arbuthnot, better known as a satirist perhaps, attacked those who underestimated rates of smallpox mortality.$^{14}$ Arbuthnot's arguments, which refuted Massey, were not significant merely because they employed demographic calculations but because they pointed out just how serious smallpox had become. And his contacts in the African Company knew he was correct. More recent analysis of the bills of mortality indicates that England faced severe smallpox epidemics in 1710,1714 , and again in 1719 , and especially throughout 1721,1722 , and $1723 . .^{15}$ Thus, the disputes over inoculation came about at a time of intense political conflict, of government efforts to defend against the plague and to repair the confidence destroyed by the South Sea Bubble. Commerce could not be considered without an awareness of contagion. That much, at least, Daniel Defoe demonstrated in The

\footnotetext{
${ }^{11}$ Ibid., 29 August 1719, p. 1520.

${ }^{12}$ Miller, op. cit., note 8 above, pp. 103-104. The sermon delivered in St Andrew's Church, Holborn, the scene of many a controversial sermon, especially after 1713 when Dr Henry Sacheverell was presented to the living. The facts that the equally high-flying Dr Charles Humphreys preached there and that one of his parishioners was the anti-Trinitarian polemicist William Whiston made for some bitter confrontations. See Weekly Journal, or, British Gazetteer, Saturday, 31 January 1719 and Saturday, 7 February 1719. A rather different view of Edmund Massey is presented in A.D. Farr, 'Medical developments and religious belief: with special reference to Europe in the eighteenth and nineteenth centuries', PhD thesis, Open University, 1977, pp. 34-35.

${ }^{13}$ Alexander Monro, senior An account of the inoculating the smallpox in Scotland, Edinburgh, 1765, pp. 5-6; also, Society for Promoting Christian Knowledge [SPCK], CN3/1, New England Letter Book, p. 40. Henry Newman to Colman, 28 September 1722.

${ }^{14}$ Miller, op. cit., note 8 above, p. 106.

${ }^{15}$ Appleby, op. cit., note 9 above, p. 22; and Creighton, op. cit., note 9 above, pp. 461, 518-519. Cf. Table I. Creighton's statistics are derived largely from James Jurin, An account of the success of inoculating the small pox in Great Britain, London, 1724.
} 


\section{Stewart}

journal of the plague year, which appeared in 1722. And by that summer it appeared that the anti-inoculators were fighting a losing battle. ${ }^{16}$

The efforts of the Royal Society to examine the process then known as "engrafting" occurred largely as a result of English commercial contacts. As we shall see, the slave trade was to play a curious, if unnoticed, part. In 1714, Richard Waller, secretary to the Society, wrote to the English consul at Smyrna requesting details of the method described in an earlier communication from Constantinople. ${ }^{17}$ But it was one of his successors as secretary, James Jurin, who undertook the major programme to evaluate inoculation and ultimately to convince the literate public of the efficacy of procuring smallpox by artificial means. Jurin, briefly a pupil of Boerhaave, held his post from 1721 to 1727 , during which time he collected and disseminated virtually all that was then known of the technique. ${ }^{18}$ Frequently, correspondence appeared in the Philosophical Transactions, and, as the public debate grew more rancourous, Jurin resolved to publish his communications in such a way "as to give no just Cause of Offence to either of the contending Parties". ${ }^{19}$ And parties, indeed, there soon developed.

Thanks to Genevieve Miller, the basic outlines of the controversy are well known. Lady Mary Wortley Montagu's public crusade and the efforts of her surgeon Charles Maitland in the spring of 1721 began a debate over the dangers of inoculation. For a time, all seemed to go well, as the results of engrafting were generally a mild illness, especially in young children. This was notably true during the summer of 1721 , when smallpox raged at various locations in England, such as Hertford and Halifax, and Hans Sloane was consulted by George I on a proposed experiment amongst felons awaiting execution at Newgate. Success with the six condemned men raised much curiosity, especially amongst the royal family, and particularly after the inoculation of a small group of charity and hospital children. By April 1722, Sloane was supervising the inoculation of two of the children of the Princess of Wales. Within days of the royal inoculations, however, news came of the death on the same day of the Earl of Sunderland and his recently inoculated young son, William Spencer. There followed several prominent deaths, such as that in 1725 of the niece of Sir John Eyles, sub-governor of the South Sea Company. ${ }^{20}$ And it was the deaths of persons of note, following inoculation, that gave pause to the practice and added fuel to the arguments of the anti-inoculators.

One could regard the inoculation campaign as being orchestrated by Hans Sloane. ${ }^{21}$ However, Jurin's perseverance and the exertions of other Fellows of the Royal Society indicate that the benefits of inoculation were of wide concern. Neither

\footnotetext{
${ }^{16}$ SPCK, CN3/1, New England Letter Book, p. 18. Henry Newman to Colman, 14 July 1722.

${ }^{17}$ Royal Society, MS 256, Sherard Letters, 5, no. 647. Waller to William Sherard, 8 July 1714; Miller, op. cit., note 8 above, p. 14 .

${ }^{18}$ Creighton, op. cit., note 9 above p. 481 . On Jurin, see E. Ashworth Underwood, Boerhaave's men at Leyden and after, Edinburgh University Press, 1977, pp. 127-128.

${ }^{19}$ Jurin, op. cit., note 15 above, p. 18. This is based on the Royal Society Inoculation Letters and Papers which deal with the issue up to 1727 .

${ }^{20}$ Creighton, op. cit., note 9 above, pp. 468-469, 489; Miller, op. cit., note 8 above, pp. 74-85, 96-97. See Robert Halsband, 'New Light on Lady Mary Wortley Montagu's contribution to inoculation',J. Hist. Med., 1953, 8: 395-399.

${ }^{21} \mathrm{Cf}$. Miller, op. cit., note 8 above, pp. 90-91.
} 
The edge of utility

TABLE I: JAMES JURIN'S CALCULATIONS OF SMALLPOX MORTALITY

\begin{tabular}{|c|c|c|c|c|}
\hline $\begin{array}{l}\text { Years } \\
1701\end{array}$ & $\begin{array}{r}\begin{array}{r}\text { Total Number } \\
\text { of Burials }\end{array} \\
20,471\end{array}$ & \multicolumn{3}{|c|}{ Died of the Smallpox } \\
\hline $\begin{array}{r}1701 \\
2 \\
3 \\
4 \\
5 \\
6 \\
7 \\
8 \\
9 \\
10 \\
11 \\
12 \\
13 \\
14 \\
15 \\
16 \\
17 \\
18 \\
19 \\
20 \\
21 \\
1722\end{array}$ & $\begin{array}{l}20,471 \\
19,481 \\
20,720 \\
22,684 \\
22,097 \\
19,847 \\
21,600 \\
21,291 \\
21,800 \\
24,620 \\
19,833 \\
21,198 \\
21,057 \\
26,569 \\
22,232 \\
24,436 \\
23,446 \\
26,523 \\
28,347 \\
25,454 \\
26,142 \\
25,750\end{array}$ & $\begin{array}{r}1,095 \\
311 \\
898 \\
1,501 \\
1,095 \\
721 \\
1,078 \\
1,687 \\
1,024 \\
3,138 \\
915 \\
1,943 \\
1,614 \\
2,810 \\
1,057 \\
2,427 \\
2,211 \\
1,884 \\
3,229 \\
1,440 \\
2,375 \\
2,167\end{array}$ & $\begin{array}{r}53 \\
16 \\
43 \\
66 \\
50 \\
36 \\
50 \\
79 \\
47 \\
127 \\
46 \\
92 \\
77 \\
106 \\
48 \\
99 \\
94 \\
71 \\
114 \\
57 \\
91 \\
84\end{array}$ & $\begin{array}{l}1 / 19 \\
1 / 163 \\
1 / 23 \\
1 / 15 \\
1 / 20 \\
1 / 28 \\
1 / 20 \\
1 / 13 \\
1 / 21 \\
1 / 8 \\
1 / 22 \\
1 / 11 \\
1113 \\
1 / 9 \\
1 / 21 \\
11 / 10 \\
1 / 11 \\
1114 \\
1 / 9 \\
1 / 18 \\
11 / 11 \\
1 / 12\end{array}$ \\
\hline 22 years & 505,598 & 36,620 & 72 & $1 / 14$ \\
\hline $\begin{array}{l}\text { each year } \\
\text { at a medium }\end{array}$ & 22,982 & 1,665 & 72 & $1 / 14$ \\
\hline
\end{tabular}

Source: Royal Society, Letter Book (C), XV. James Jurin to Dr. Cotesworth. Read before the Society, 17 January 1722/3.

was this interest without any theoretical framework, albeit a very vague if exceedingly popular one. The followers of Newton took the opportunity to examine the physics of the Opticks, especially for notions of air as an elastic fluid which might help explain the phenomena of contagion of epidemic diseases as well as legitimize active intervention in their prevention. It became a commonplace in the eighteenth century in discussions of outbreaks of smallpox or plague to find observations of the weather, which would give rise to speculation of the conditions that made epidemics intelligible. Thus, John Huxham writing to Jurin about smallpox at Plymouth in 1724 and 1725, suggested that the "viscous, tough Humors" might "depend on the extraordinary Driness of the Season". ${ }^{22}$ Similarly, writing in a work dedicated to Richard Mead and "founded on the Principles of the Newtonian Philosophy", Nicholas Robinson pointed out that from "hot, sulphrous Air . . . arise . . those Nervose, Epidemic, and, as some will have them, Malignant Fevers, that so frequently attend about the Months of July and August, as also that Fatality of Small Pox, so arise about those Times." 23 Thus, Robinson went on to argue, "The Air most generally is the remote Cause of Malignant Fevers, and when they are Epidemical, and a general Disease. . . This is the Reason why Turkey and the Parts adjacent are

${ }^{22}$ Phil. Trans., no.390 September-October 1725, 382-383; Royal Society MSS, Inoculation Letters and Papers, 22 July 1725, pp. 259-263. See Gordon Manley, 'The weather and diseases: some eighteenthcentury contributions to observational meteorology', Notes Rec. R. Soc. Lond., 1952, 9: 300-307.

${ }^{23}$ Nicholas Robinson, $A$ new theory of physick and diseases, London, 1725. p. 62. 


\section{Stewart}

so infested with Plagues, and other Malignant Diseases, because the Air, settling in the same Corner for the greatest Part of the Year, loses its Current, and by that Means acquires an infectious Miasma, which destroys frequently both Men and Beasts;. . . .",24

It was because of notions such as these, and not simply the foetid conditions of the lower decks of the British Navy, that the Reverend Stephen Hales, the brewer Samuel Sutton, and John Theophilus Desaguliers developed the ventilating apparatus in the early part of the century..$^{25}$ Although Desaguliers was a Doctor of Divinity, rather than a physician, among his many interests was the nature of the smallpox. He was one of those sufficiently convinced of the desirability of inoculation that when his one-year-old daughter caught the smallpox naturally in 1723, Desaguliers not only decided to have his four-year-old son inoculated with matter taken from her pustules but he also examined under a microscope and sketched the "irregular Globules" of the smallpox. ${ }^{26}$ Desaguliers' interest may well have been spurred by his close association with the Duke of Chandos. ${ }^{27}$

\section{DISEASE, TRADE, AND THE AFRICAN COMPANY}

The role of the Royal Society in the inoculation campaign has largely been understood as the effort of a few society physicians like Hans Sloane or Richard Mead. But it was much more than that. It was part of a general interest in contagion and especially the relationship between the British trade routes and epidemiology. This interest grew out of a network of communication which Sloane assiduously cultivated through his influence with the South Sea Company and the African Company in particular. From time to time, commerce afforded the Royal Society marvellous opportunities for contact with distant travellers and for the collection of the many specimens that found their way to London. The links between the Society and the companies could sometimes be quite direct. James Brydges, the first Duke of Chandos, and since 1694 a Fellow of the Royal Society, became an active member of the Court of Assistants of the African Company during the 1720s. In this role, late in 1721, Chandos took the initiative in a correspondence with Sloane to secure his advice in the matter of trade in herbs, spices, and drugs, which the Company hoped to turn to advantage. In December, Chandos was especially anxious to secure Sloane's advice on sending to the African Company's settlements a knowledgeable botanist. ${ }^{28}$ By the end of the month, Francis Lynn, Secretary to the African Company, had prepared three chests of drugs to be sent to Gambia, Sierra Leone, and the Gold Coast to assist in the questioning of slaves to determine whether they were familiar

\footnotetext{
${ }^{24}$ Ibid., p. 130. On contagion, see also Roger Cooter, 'Anti-contagionism and history's medical record', in Peter Wright and Andrew Treacher (editors), The problem of medical knowledge, Edinburgh University Press, 1982, esp. pp. 94-97.

${ }^{25}$ D.G.C. Allen and R.E. Schofield, Stephen Hales: scientist and philanthropist, London, Scolar Press, 1980 , pp. 85-89.

${ }^{26}$ Royal Society, Register Book (C), XI, 372-373, 'An account of the appearance of the matter of the small pox thro' a microscope', 14 June 1723.

${ }^{27}$ Desaguliers' career, interwoven with the machinations and adventures of the Duke of Chandos, will be dealt with in a forthcoming work on the early Newtonians.

${ }^{28} \mathrm{BL}$, Sloane MSS 4046, fols. 152-153, Chandos to Sloane, 4 December 1721; f. 156, Chandos to Sloane, 7 December 1721.
} 
with any sources the Company might exploit. ${ }^{29}$ In May 1722, Chandos passed on to the Company factor at Wydah Sloane's request that plants be gathered while bearing fruit and flower and sent intact. ${ }^{30}$ Similarly, Sloane's relations with Sir John Eyles, sub-governor of the South Sea Company, offered an opportunity to exercise some influence on behalf of John Burnet, a surgeon of the South Sea Asiento factory at Cartagena. ${ }^{31}$ Burnet, later Physician to Philip V of Spain, begged the assistance of Sloane throughout the 1720 s to protect him in London against "groundless and Malicious" complaints within the Company. ${ }^{32}$ Burnet kept in Sloane's good graces by sending him the collections and specimens he desired, along with news of the Spanish dominions. While Sloane told Burnet of the rage for smallpox inoculation, Burnet reported on a case of distemper called St Lazaro's at Cartagena involving a young boy who was seized with smallpox on top of the abscesses; querying, "whether inoculating the Small pox on the Lazarens would not prove a Cure?" ${ }^{33}$

Sloane's scientific collections grew with his correspondence. He relied very largely on medical men, although not all were in the employ of the chartered companies. For example, the Scottish physician Walter Tullideph established a practice in Antigua whence he corresponded with Sloane and shipped various specimens. ${ }^{34}$ Generally, however, Sloane's interests were fairly consistently served by the agents of the South Sea Company in the Caribbean. When John Burnet returned to Europe, Sloane was to owe much to Dr William Houstoun, one of Boerhaave's students, who sent collections to London until his death in $1733 .^{35}$ Both Burnet and William Houstoun were acquainted with and assisted by Dr James Houstoun, whose career spanned both the African Company and the South Sea Company. ${ }^{36}$ James Houstoun who, like the others, searched for samples of herbs and drugs on behalf of the African Company-about which Sloane had been consulted-had a far more varied and bizarre career than his associates. From Africa to the Caribbean along the routes of the slave trade, James Houstoun sought botanical specimens, looked out for the

${ }^{29}$ BL, Sloane MSS 4046, f. 166, Lynn to Sloane, 29 December 1721; Public Record Office [PRO], T70/46/111, Royal African Company, Home Letter Book No. 5, Lynn to Mr Goodwin, 28 December 1721.

${ }^{30}$ Huntington Library [Hunt. Lib.], San Marino, California, Stowe MSS 57, XVIII, f.435, Chandos to Ambrose Baldwin, 11 May 1722.

${ }^{31}$ Raymond P. Stearns, Science in the British Colonies of America, Urbana, University of Illinois Press, 1970, pp. 384-388. For Eyles, see Richard Romney Sedgwick (editor), The House of. Commons, 1715-1754, 2 vols., London, HMSO, 1970, vol. 2, p. 21.

${ }^{32}$ BL, Sloane MSS 4048, f.120, Burnet to Sloane, 5 January 1725[/6?]: f.70, Burnet to Sloane, 6 October 1725.

${ }^{33}$ BL, Sloane MSS 4047, f.333, Burnet to Sloane, 7 April 1725.

${ }^{34}$ Richard B. Sheridan, 'Mortality and the medical treatment of slaves in the British West Indies', in Stanley L. Engerman and Eugene D. Genovese (editors), Race and slavery in the western hemisphere: quantitative studies, Princeton University Press, 1975, pp. 302-303.

${ }^{35}$ Stearns, op. cit. note 31 above, pp. 327-303; Blanche Henrey, British botanical and horticultural literature before 1800, 3 vols. London, Oxford University Press, 1975, vol. 2, pp. 175-177.

${ }^{36}$ BL, Sloane MSS 4048, f.70, Burnet to Sloane, 6 October 1725; Sloane MSS 4051, fols. 86-87, James Houstoun to Sloane, 16 August 1730; and Sloane MSS 4052, f.82, William Houstoun to Sloane, 5 March 1721. James and William, who knew one another well, should not be confused; still less with the gynaecologist Robert Houstoun with whom James had a connexion through Lady Anne Houstoun and the Jacobite Earl of Melfort. Cf. C. John Mackinlay, 'Who is Houstoun? a biography of Robert Houstoun, MD, FRS, 1678-1734', J. Obstet. Gynaec. Br. Commonw., 1973, 80: 194-195. 


\section{Stewart}

health of gold miners who died in droves of tropical diseases or epidemic European infections, and tried his hand at assessing potash and the production of soap. ${ }^{37}$ In all of this, members of the Royal Society were also deeply involved. To a considerable degree, this co-operation of trade with natural philosophy was formed in the aftermath of the South Sea crisis of 1720 .

The relations between the Royal Society and the Royal African Company are significant in that they represent the efforts of a company in difficulty attempting to exploit all the expertise at its disposal. It might be going too far to suggest that this was an expressly formal relationship. Nonetheless, as in other enterprises such as the development of steam-engines, individual members of the Royal Society were frequently consulted in an effort to secure the investment of the shareholders in joint-stock companies. This was especially true after the Bubble when the future of many such enterprises was in grave doubt. ${ }^{38}$ In particular, the Duke of Chandos infused new life and new money into the sagging fortunes of the African Company, in part by utilizing his access to the Royal Society. The resulting revival of the Company was to prove a temporary affair. Chandos recognized very quickly that "The Slave Trade is a Losing Trade" but this determination led to the effort to shift the trade from slaves to ivory, to gold for which prospects appeared very bright, and to cotton, potash, and drugs. ${ }^{39}$ To Chandos, medicine and profit in the trade were directly linked. Even more directly, Chandos's motives were fashioned by what was on many minds in 1721-smallpox. By 1721, Chandos, who had managed to secure control of the Court of Assistants, wrote directly to James Phipps, Captain General at Cape Coast Castle, "to enquire into the Physick the Natives use for curing distemper, \& if they have any Specificks to find out, of what they are made, $\&$ to send over some of their drugs with an Account of their Nature, \& how used \& in what quantities, viz. for Fevers, fluxs, \&c. ..."40

Chandos's request for news of medicines must have struck Phipps as not a little ironic. For years, the Company had been informed of the perilous state of health of the employees on the African coast, not to mention that of the captives crowded into the "trunck" awaiting shipment." And matters turned suddenly much worse at the very time that Chandos was trying to rescue the Company by finding other commodities. By the end of 1721, the Africa merchants were well aware of the

\footnotetext{
${ }^{37}$ James Houstoun, MD, Some new and accurate observations geographical, natural and historical. Containing a true and impartial account of the situation, product, and natural history of the Coast of Guinea, So far as relates to the improvement of that trade, for the advantage of Great Britain in general, and the Royal African Company in particular, London, 1725, pp. 4-5, 12-13, 23.

${ }^{38}$ See A. B. Dubois, The English business company after the Bubble Act, 1720-1800, New York, Columbia School of Law, 1938.

${ }^{39}$ Hunt. Lib., Stowe MSS 57, XXI, f. 13, Chandos to Ambrose Baldwin at Wydah, 7 July 1722. See K. G. Davies, The Royal African Company London, Longmans, Green, 1957, pp. 344-345.

${ }^{40}$ Hunt. Lib., Stowe MSS 57, XIX, f. 222, Chandos to James Phipps, 5 October 1721. See also, Houstoun, op. cit., note 1 above, pp. 126-127. Chandos's control of the Company was exercised through the Court of Assistants, many of whom had been connected with him for some time, such as his banker John Drummond and the goldsmith John Mead. Others involved were John Essington and the M.P.s, Martin Bladen and Richard Lockwood. For example, see PRO, T70/116/24, African Company, Committee Book of Accounts, 28 January 1724.

${ }^{1}$ Colin Palmer, Human cargoes. The British slave trade to Spanish America, 1700-1739, University of Chicago Press, 1981. p. 43.
} 


\section{The edge of utility}

deteriorating situation, as they put it, of "a Country So different from their Own, surrounded with the melancholy \& repeated instances of Mortality. . .". ${ }^{42}$ It was not, however, until February 1722 that the Company learned the more precise nature of the crisis they were facing and began to take lessons from the London situation. At that point, the Court of Assistants received word from Captain Samuel Barlow, the commander of a frigate from Wydah, which had arrived in Barbados on 20 November 1721 with 129 of the cargo of 371 slaves lost at sea. ${ }^{43}$ Barlow had sailed from Wydah in the first week of September, at which point the factor Ambrose Baldwin also dispatched a letter reporting that his surgeon and surgeon's mate were both dead. ${ }^{44}$ Barlow's letter arrived in London on 13 February and by 22 February the Court heard a petition from Dr James Houstoun to be employed as a chief surgeon at one of the Company's settlements. ${ }^{45}$ What the Court did not know was that at the moment of Houstoun's employment desperate letters were also being written of a great mortality at Sierra Leone. ${ }^{46}$

If Houstoun's request seemed propitious, it certainly was not coincidental. His petition had been drawn up by one of the Assistants, John Drummond, who was also Chandos's personal banker, and the recommendation was made by the Duke's favourite, John Arbuthnot. ${ }^{47}$ Not surprisingly, Arbuthnot was involved in the affairs of the Company, as were Hans Sloane and Chandos's physician, Dr Henry Levett. ${ }^{48}$ Chandos, through Arbuthnot, had recruited the Scottish surgeon for his medical knowledge and as a kind of comptroller to ensure that the slaves that were shipped were healthy enough to survive the passage. The recent disasters in the slave trade, it turned out, were attributed to the most ubiquitous of diseases, as he shortly informed Baldwin at Wydah: “. . . The Mortallity wch. hath happen'd to ye Negroes by ye. small Pox hath made ye. Comp: resolve to try the method of Inoculation wch. is begun to be practic'd in England and hath not fail'd to succeed in every Instance you have a Direction in our Publick Letter to put it in Practice and Dr. Houston is very well acquainted wth. ye. Method of it."49

Chandos's appreciation of inoculation on the English scene may seem a trifle generous; but he was not alone in his views. Lady Mary Wortley Montagu, who is

\footnotetext{
${ }^{42}$ PRO, T70/53/105, Africa Company to James Phipps, 12 September 1721. Also T70/53/141, to Phipps, 20 November 1721.

${ }^{43}$ PRO, T70/91/102, Minutes of the Court of Assistants. 13 February 1721[/22]: T70/1439/11, List of the Ships' Crews and Passengers on board the Africa Company's vessels for Africa. Barbados records, however, indicate 376 slaves imported by Barlow on that date although, in view of the circumstances, this is probably an error. Barbados Department of Archives, List of Vessels 1708-1726. I owe this reference to the Chief Archivist, E. Christine Matthews. The voyage does not appear to have been inordinately long. Cf. Herbert S. Klein, The middle passage, Princeton University Press, 1978, p. 199.

${ }^{44}$ PRO, T70/7/39, Abstracts of Letters, 1719-1732, Baldwin to Court, 7 September 1721.

${ }^{45}$ PRO, T70/91/106, Minutes, 22 February $1721[/ 22]$.

${ }^{46} \mathrm{PRO}, \mathrm{T} 70 / 7 / 36-7$, Abstracts, received 23 May 1722 . The only independent reference I can locate is of drought and famine on the Niger Bend in 1721-1722 and a smallpox epidemic on the Gambia in 1724. Philip D. Curtin, Economic change in precolonial A frica, Supplement, Madison, University of Wisconsin Press, 1975, p. 5.

${ }^{47}$ PRO, T70/91/106, 22 February 1721[/22]; Houstoun, op. cit., note 1 above, pp. 77, 127-128.

${ }^{48}$ PRO, T70/91, Minutes of the Court of Assistants, fols. 11, 24 August 1721; 13, 29 August 1721; 18-19 12 September 1721; 29-30, 28 September 1721; and Hunt. Lib., Stowe MSS 57, XX (MS film 417), f. 218. Chandos to Levett, 12 May 1722; XXII, f. 201. Chandos to Levett, 18 March 1723.

${ }^{49}$ Hunt. Lib., Stowe MSS 57, XVIII, f. 389. Chandos to Baldwin, 3 March 1721/2.
} 


\section{Stewart}

renowned as a promoter of the technique, was even more enthusiastic. ${ }^{50}$ Certainly, the contemporary reports reflected enormous optimism against a disease that ranged so freely and often with such catastrophic results. What is remarkable is the degree of caution most medical authorities applied in the English circumstances-while slaves, of course, had no chance to object to the experiment. And it was in the Royal Society-in the circles of Chandos, Sloane, and Arbuthnot-that inoculation received its most detailed scrutiny.

\section{SMALLPOX, SLAVERY, AND INOCULATION}

When Chandos and Arbuthnot contrived the employment of James Houstoun as surgeon, they had personal as well as economic motives. Arbuthnot's interest in smallpox and inoculation was obvious, and Chandos had recently a personal involvement when his young son, he hoped, had a mild attack of smallpox while on the Grand Tour in Holland late in $1721 .{ }^{51}$ But there can be no doubt that economic purpose predominated. From the evidence available, it seems that smallpox was endemic in the slave trade during the early eighteenth century, although as far as the Europeans were concerned it may well be considered only one of a number of the eruptive fevers that proved so fatal. Outbreaks of smallpox both at the Company's forts on the African coast and on board the slave vessels were continually reported among the major causes of slave mortality, as in 1708,1713 , and $1716 .^{52}$ In 1734 , the surgeon John Atkins reported that the centre of the slave trade at Wydah was "Subject to Small-Pox and sore Eyes" [ophthalmia]. ${ }^{53}$ Certainly, the Assistants of the African Company were conscious of the situation and at least as early as $\mathbf{1 7 2 0}$ tried to institute a systematic method of recording the "Nature and Cause of every Distemper, the way of cure, and the reason for it". ${ }^{54}$ There is no reason to suspect that such a diary was not kept by the Company's servants, for such a proposal was reinforced by suggestions from Dr Stewart, one of the slave commissioners at Jamaica, that journals be kept by shipboard surgeons. Even more significantly, in December 1722, the Company ordered the application of Stewart's suggestions "touching the preservation of the health of the Negroes". ${ }^{55}$ What had spurred this action was not only the severity of the losses of Captain Barlow a year earlier but the more recent deaths of 100 slaves bound for Jamaica on board the Carleton "by ye Small Pox", which, according to Chandos, "shows the Necessity of trying to Prevent

\footnotetext{
${ }^{50}$ Robert Halsband (editor), The complete letters of Lady Mary Wortley Montagu, Oxford University Press, 1966, vol. 2, p. 15. Montagu to Lady Mary, April 1722. Lady Mary's role in the subsequent controversy is dealt with in Miller, op. cit., note 8 above, pp. $72 \mathrm{ff}$.

${ }^{51}$ Hunt. Lib., Stowe MSS 57, XVIII, f. 346, Chandos to Dr Stewart, 3 January 1721/22. This may have been to Dr Alexander Stewart, FRS, the protégé of Sloane. See Underwood, op. cit., note 18 above, pp. 132-133, 151-152. Cf. C. H. Collins Baker and Muriel I. Baker, The life and circumstances of James Brydges, First Duke of Chandos, Oxford University Press, 1949, p. 238.

${ }^{52}$ Palmer, op. cit., note 41 above, p. 49.

${ }^{53}$ John Atkins, The navy-surgeon: or, a practical system of surgery . . . also an appendix, containing physical observations of the heat, moisture, and density of the air on the Coast of Guinea: the colour of the natives; the sickness which they and the Europeans trading thither are subject to; with a method of cure, London, 1734, Appendix, p. 17.

${ }^{54}$ PRO, T70/66/7, no. 26, 'Copy of the Instructions of the Royal African Company of England to their Chief Agents in Africa, No.1', to David Dunbar at Gambia, 6 October 1720.

${ }^{55}$ PRO, T70/137/10, 34. Orders of the Court, 2 March 1721/2, 5 September 1722; T70/91/188. Minutes of the Court of Assistants, 5 December 1722; Baker and Baker, op. cit., note 51 above, p. 211.
} 


\section{The edge of utility}

it by inoculation the Mannr. of wch. Dr. Houstoun is acquainted with". ${ }^{56}$

There can be little doubt that the enthusiasm in the Royal Society for inoculation and the public debate about it encouraged the African Company to hope smallpox could at least be controlled in the slave trade. Such, certainly, was the background to Chandos's and Arbuthnot's efforts on behalf of James Houstoun. And the instructions of the Company to their factors in Africa were quite specific. The Court of Assistants, including Chandos, was of the opinion that inoculation "would be of great advantage to Us, could it be put in practise by saving the Lives of great Numbers of Slaves, amongst whom the Small Pox is very fatall, especially, when it seizes them on their Voyage. ..". ${ }^{57}$ James Phipps, at Cape Coast Castle, was ordered to have some trials of the method made by Houstoun. The medical situation had become quite desperate in the trade, although not entirely because of smallpox. At Cabinda, on the Congo coast, woods were systematically cut down to make the settlement more healthy, and the British on the Gambia feared plague from the French to the north on Goree Island. ${ }^{58}$ In these circumstances, it is remarkable that Phipps, while agreeing to attempt inoculation upon Houstoun's arrival if the opportunity arose, was certain that the natives of the Gold Coast were "not much subject to the Small pox" ${ }^{59}$ Nonetheless, the Company was convinced that smallpox had been the cause of their recent disasters and they were determined that James Houstoun should do something about it.

Houstoun sailed from Gravesend aboard the Diligence at the end of April 1722, arriving at Sierra Leone by early July. ${ }^{60}$ When he reached Cape Coast Castle some time before the end of August, the settlement was in difficult circumstances. The miners earlier recruited by Chandos to search for gold-in the hope of rescuing the prospects of the Company-were mostly dead; the remainder were afraid to venture out of reach of the guns of the fort as the result of disputes with the local natives. ${ }^{61}$ Houstoun's eventual destination was to be Wydah, which he did not sight until 17 November and where all the good intentions of the Company began to disintegrate in the tropical climate..$^{62}$ It was the doctor's responsibility to ensure that the slaves put on board the company's vessels were "merchantable". This eventually caused him to run foul of Ambrose Baldwin, the chief factor at Wydah, who apparently had been selling to Portuguese slavers while the Company would have to wait to fill its ships. The result was that Houstoun was imprisoned in a small dungeon for thirty-three days and at the end of 1723 was shipped to Jamaica. ${ }^{63}$ By the time Houstoun reached London in 1724, the whole medical effort had been an apparent failure, thanks to the

${ }^{56}$ Hunt. Lib., Stowe MSS 57, XXI, f. 16, Chandos to Baldwin, 7 July 1722.

${ }^{57}$ PRO, T70/53/169, Court of Assistants to James Phipps, et al., 13 March 1721/2.

${ }^{58}$ PRO, T70/7/50,56, Abstracts of Letters Received, Captain Hereford, Cabinda, 20 October 1722; Glynn and Willey, Gambia, 15 November 1722.

${ }^{59}$ PRO, T70/7/42, Phipps, Cape Coast Castle, 9 June 1722.

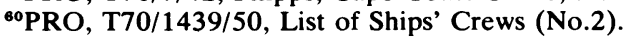

${ }^{61}$ PRO, T70/7/52, Abstracts, Cape Coast Castle, 31 August 1722; and, Houston, op. cit., note 37 above, pp. 2,23. This version is confirmed by Phipps, T70/7/44-45, Cape Coast Castle, 2 July 1722, Cf. Houstoun, op. cit., note 1 above, p. 130.

${ }^{62} \mathrm{PRO}, \mathrm{T} 70 / 7 / 49$, Abstracts, Wydah, 21 January 1722/23.

${ }^{63}$ Houstoun, op. cit., note 37 above, pp. 26ff; and op. cit., note 1 above, pp. 140-141. PRO, T70/7/80, Abstracts, Baldwin, Wydah, 12 January 1723/4; T70/1446/82-90, 117-118. List of the Living and Dead at the Royal African Company's Forts. 


\section{Stewart}

interference of Baldwin. In any event, what is important is the length to which the Company was willing to go with a new medical technique. ${ }^{64}$ For his part, Chandos does not seem to have blamed Houstoun, for he introduced him to Sir John Eyles and as a result Houstoun obtained an appointment as surgeon to the Royal Asiento factory at Cartagena. ${ }^{65}$

The recruitment of James Houstoun represents a deliberate policy to try to control the epidemiological factors that appeared to be undermining the base of the African Company. It is, therefore, curious that in the report of his adventures which he published in 1725, Houstoun makes no mention of smallpox inoculation, perhaps because he never had the opportunity to attempt it from his cell. Nonetheless, he does engage in discussion of the myriad of fevers which, with dysentery, proved so fatal to the Europeans in the trade ${ }^{68}$ Encountering new diseases for which they had no immunity caused astronomical mortality rates. This was true in every aspect of the trade, whether on the Gold Coast in the early 1720s, in the West Indies, or indeed on board the slave ships themselves where, evidence indicates, mortality rates were higher for Europeans than for the slaves. ${ }^{67}$ Moreover, the rigours of the ships' holds and the treatment received on shore awaiting passage did little to impede epidemics like smallpox, which then infected captive and captor alike. It was precisely for this reason, in the circumstances of the early 1720 s, that the African Company ordered its Captain General at Cape Coast to improve the holding areas, since "For want of good and Sufficient Lodgements for the Negroes in the Castle, we find very great Mortality has attended them. . ." ${ }^{68}$ Given that epidemics such as smallpox had been known to Europeans on the Guinea Coast at least as early as 1664 and well into the eighteenth century, the African Company, alert to the medical debate, saw no reason to stand idly by in $1721 . .^{69}$

The initial enthusiasm over inoculation early in 1722 presented the African Company with an opportunity to control smallpox outbreaks within its trade and thus to protect its profits. Houstoun's role in the introduction of the method into the trade is unclear; all we know for certain was the intention. Moreover, it has been suggested that the practice may have been indigenous to some parts of Africa, although the evidence, especially for the west coast, is not even remotely conclusive before the

\footnotetext{
${ }^{64}$ Houstoun, op. cit., note 1 above, pp. 131-133. By 1724, Houstoun's fortunes were at a very low ebb. Probably because of debt, he assigned his salary to a Robert Cooper. PRO, T70/92/108, 10 September 1724.

${ }^{65}$ Houstoun, op. cit., note 1 above, pp. 156-157, 182.

${ }^{66}$ Houstoun, op. cit., note 37 above, pp. $52 \mathrm{ff}$.

${ }^{67}$ H. M. Feinberg, 'New data on European mortality in West Africa: the Dutch on the Gold Coast, 1719-1760', J. Afr. Hist., 1974, 15: 363-365; and Philip D. Curtin, 'Epidemiology and the slave trade', Pol. Sci. Q., June 1968, 83: 204, 208. Thus, losses of slaves cannot simply be attributed to crowding alone but rather to epidemiological factors which caused high crew mortality on ships with high slave mortality. See Herbert S. Klein and Stanley L. Engerman, 'A note on mortality in the French slave trade in the eighteenth century', in Henry A. Gemery and Jan S. Hogendorn (editors), The uncommon market: essays in the economic history of the Atlantic slave trade, New York and London, Academic Press, 1979, pp. 263-269.

${ }^{68} \mathrm{Joseph}$ C. Miller, 'Mortality in the Atlantic slave trade: statistical evidence on causality',J. interdiscip. Hist., 1981, 11: 409-412; PRO, T70/53/193, to Henry Dodson, Cape Coast Castle, 8 February 1722/3.

${ }^{69}$ See J. G. Breman, A. B. Alecaut, and J. M. Lane, 'Smallpox in the Republic of Guinea, West Africa', Am. J. trop. Med. Hyg., 1977, 26: 757; Feinberg, op. cit., note 67 above, p. 362.
} 
nineteenth century. The exception appears to be on the Barbary Coast, as the Boston minister, Cotton Mather, informed Dr John Woodward after having read a report in the Philosophical Transactions of 1714 and subsequently having questioned his own slave. But as far as the European slave trade is concerned, it was not until the 1770s that evidence became more certain-when a French captain inoculated both crew and slaves to check an outbreak, and not until 1789 when inoculation was used during an epidemic at Cape Coast Castle. ${ }^{70}$

If the African evidence is in dispute, and efforts of the African Company in the early eighteenth century simply overlooked, then the Caribbean end of the slave trade tells a different tale. Smallpox was as endemic amongst the slave populations of the West Indies as of Africa. In 1732, the Nevis minister Robert Robertson noted the havoc smallpox created amongst the blacks. ${ }^{71}$ And on the Codrington plantations of Barbados in the 1740s, the manager Abel Alleyne reported fever and a smallpox epidemic. ${ }^{72}$ It is no surprise in these conditions that tales circulated of intervention by way of inoculation. Mather reported to London that he had heard that slave captains inoculated their cargoes to ensure they fetched a better price. ${ }^{73}$ While the evidence is inconclusive about the truth of the stories told to Mather, by mid-century, the French mathematician La Condamine had calculated the savings inoculation of slaves could bring to a plantation owner. La Condamine reported a case of a Carmelite missionary in Brazil inoculating native Indians, possibly as early as 1730 after having read of the great debate in Europe. ${ }^{74}$ When smallpox was imported into Boston from the Barbados by April 1721, at the very moment Lady Mary Wortley Montagu undertook her crusade and shortly before the deaths on the African vessels, the tales Mather had heard began to sound credible. ${ }^{75}$

Despite the apparent benefits of inoculation, opposition intensified throughout the 1720 s as much on moral grounds as on medical uncertainty. The anonymous author of a pamphlet demanding parliamentary regulation of the practice was not alone in regarding inoculation "as a Thing utterly unlawful in it self" and as "a thing forbidden in Scripture". ${ }^{76}$ Nonetheless, the English author did notice the catastrophic effect of smallpox on North American natives "among whom, it is

\footnotetext{
${ }^{70}$ The issue is best examined in Eugenia W. Herbert, 'Smallpox inoculation in Africa', J. Afr. Hist., 1975, 16: 539-559. See Bryan Edwards, The history, civil and commercial, of the British West Indies, 5th ed., London, 1819, vol. 2, pp. 166-167. On the Boston situation, see Ola Elizabeth Winslow, A destroying angel: the conquest of smallpox in Colonial Boston, Boston, Mass., Houghton Mifflin, 1974; and especially, Perry Miller, The New England mind: from colony to province, Cambridge, Mass., Harvard University Press, 1953, pp. 345-366. 21.

${ }^{71}$ Richard B. Sheridan, 'Africa and the Caribbean in the Atlantic slave trade', Am. Hist. Rev., 1972, 77:

${ }^{72} \mathrm{~J}$. Harry Bennett jun., Bondsmen and bishops. Slavery and apprenticeship on the Codrington Plantations of Barbados, 1710-1738, Berkeley and Los Angeles, University of California Press, 1958, p. 56.

${ }^{73}$ Herbert, op. cit., note 70 above, p. 540.

${ }^{74}$ Creighton, op. cit., note 9 above, p. $468 ;$ M. de la Condamine, $A$ succinct abridgment of a voyage made within the inland parts of South-America; from the coasts of the South-Sea to the coasts of Brazil and Guiana, down the river of the Amazons, 2nd ed., Paris, 1746; Eng. trans., London, 1747, pp. 92-93.

${ }^{75}$ Cf. John Duffy, Epidemics in Colonial America, Baton Rouge, Louisiana State University Press, 1953, pp. 50-51, 105.

${ }^{76}$ [Anon.], The new practice of inoculating the small-pox consider'd, and an humble application to the approaching parliament for the regulation of that dangerous experiment, London, 1722, pp. 8-9.
} 


\section{Stewart}

mortal like the Plague". A similar tone was struck the previous year by an unknown colonial antagonist whose recognition that inoculation was practised by the "scattered Members of the good people of Guinea" was one of condemnation rather than of recommendation. ${ }^{77}$ The extent of inoculation amongst the slaves became a key element in the debate over the practice. One of the more rational of the antagonists, Dr William Douglass of Boston, recognized the African source of the technique but also in direct relation to the traffic in slaves, "So that the first Intention of Inoculation was not the Saving of Life, but as a more ready way of procuring the Small-Pox, than by accidental Infection; that they might know what Beauties were proof and would answer the charge of being carried to Market." ${ }^{\text {"78 }}$ On the other side of the issue was the formidable Rev. Cotton Mather, who saw opposition to inoculation as "Satanic" indicated by the "Railing, the lying, the Fury, the Bloody Malice" which was fomented by Jacobites and High-Flyers. ${ }^{79}$ This bitterness, in a letter to James Jurin in 1723, was symptomatic of how both sides of the debate could see the medical evidence and draw the conclusions that suited them. While Douglass saw inoculation in terms of crass profit in the slave trade, Mather took heart from the evidence, seeing slaves as auxiliaries and noting that experiments had been performed on hundreds of whites and blacks in Boston.

There can be little doubt that slaves afforded the surgeons the opportunity to utilize a practice others were afraid might actually spread smallpox rather than check it. Mather was successful in urging Dr Zabdiel Boylston to inoculate his own slaves. ${ }^{\mathbf{8 0}}$ But Douglass chose to see the more fearsome possibilities, especially at the end of 1721, when he noted the potential amongst "the Guinea Traders, when the Small Pox gets among their Slaves aboard to inoculate the whole Cargo, and patch them up for a Market; as is already the Practice with them in the other Pox or Yaws, by some slight, palliative Cure to fit them up for a Market; tho' to the great Damage of the next Purchasers". ${ }^{81}$ Perhaps Douglass was afraid inoculation might merely mask smallpox symptoms. In other words, precisely one month after the arrival in Barbados of Captain Barlow's ill-fated voyage, Douglass was asserting that slavers were making use of inoculation for their own profit, whatever the dangerous consequences might be. Even though fear of inoculation increased, the experiments of the surgeons continued sporadically, as the reports sent to James Jurin indicate. Dr French of Bristol inoculated a Negro boy in 1724, and by that date very serious consideration was being given to the degree of immunity that might be afforded by the technique. ${ }^{82}$ In the same year, Philip Rose took note that the Turks had tried inoculation both in the plague and in smallpox, but with plague they were unsuccessful and were forced to rely on providence and God's will while they

\footnotetext{
${ }^{77}$ See Miller, op. cit., note 70 above, pp. 363-365; [Anon.], A letter from one in the country, to his friend in the city: in relation to their distresses occasioned by the doubtful and prevailing practice of the inoculation of the smallpox, Boston, 1721, p. 2.

${ }^{78}$ [William Douglass], A dissertation concerning inoculation of the smallpox, Boston, 1730, pp. 1-2. On Douglass, see Miller, op. cit., note 70 above, pp. 350ff; and, Duffy, op. cit., note 75 above, p. 30. 1723.

${ }^{7}$ Royal Society, Inoculation Letters and Papers, pp. 34-48, Cotton Mather to James Jurin, 21 May 4IPMiller, op. cit., note 8 above, pp. 92-93.

81 [William Douglass], Inoculation of the small pox as practised in Boston, Boston, 1722, p. 20.

${ }^{82}$ Royal Society, Inoculation Letters and Papers, p. 140, Dr Ed. French to James Jurin, 21 April 1724.
} 
violated those precepts in the smallpox. ${ }^{83}$ Nevertheless, within three years, Rose revealed that in the West Indies, and particularly, the "Gentlemen who are Possessed of Plantations in the British Colonies of America have wonderfully preserved their Negroes, by using Inoculation" ${ }^{84}$ Twenty years later, Richard Mead noted the success of the owner of a sugar plantation on St Christopher's, who inoculated 300 of his own slaves during a smallpox epidemic..$^{85}$ Thus, the conditions of the slave trade provided an available laboratory in which inoculation could be practised, while English aristocrats became increasingly reluctant to try the experiment. And experiment it was, as there was neither consensus nor evidence sufficiently compelling to overcome the general anxiety.

The critical question was the degree of immunity provided by a previous exposure to smallpox either through artificial or natural means. It was inevitable that the deaths of some prominent individuals should give pause to the initial enthusiasm, but even such an eminent physician as John Huxham of Plymouth was not convinced of the immunity provided by a previous infection. ${ }^{86}$ Jurin never tried to avoid this troubling issue. He reported to the Royal Society on a case of a nurse who apparently, having contracted the disease as a child, nonetheless was subsequently infected "by ye immediate \& close application of ye Variolose Matters to her Skin" but only appearing on the parts where there had been contact. From this, Jurin concluded that the usual symptoms of the disease and a general eruption were not possible to those who had previously suffered. ${ }^{87}$ Therefore, it was not out of ignorance or superstition, but out of a rational concern, that the number of inoculations in England dropped off rapidly after $1724 .^{88}$ Henry Newman, secretary to the Society for Promoting Christian Knowledge, knew "many learned Physicians" in 1727 who retained "their prejudices against it notwithstanding the Reasonings in Defence of Inoculation that have been given to the publick by Dr. Jurin and others" ${ }^{89}$ The most certain method of checking the disease remained the quarantine which had appeared so effective against the plague. By the 1730s, English traders in the Asiento were subject to strict examinations before slaves could be disembarked in the Spanish dominions. In 1737, slaves embarked from Barbados for sale in Spanish territory were discovered to be infected with smallpox and the captain forced to observe forty-days' quarantine after the disease had run its course. The South Sea Company agent at Caracas, Thomas Butcher, reported the necessity of strictly observing the visits of health, as the inspections were known, in part to satisfy the

\footnotetext{
${ }^{83}$ Philip Rose, An essay on the small-pox; whether natural or inoculated. Shewing that by a new and particular method, the dangerous symptoms, and fatal consequences, in either sort, may be prevented, or removed, and many lives saved, London, 1724, p. 7.

${ }^{84}$ Ibid., 2nd. ed., London, 1727, p. 85.

${ }^{85}$ Mead, op. cit., note 7 above, pp. 54-55. See Miller, op. cit., note 8 above, p. 125.

${ }^{86}$ Royal Society, Classified Papers (1660-1740), V, 'The Weather', 41. Dr J. Huxham to Jurin, 2 February 1724/5. On Huxham, see Underwood, op. cit., note 18 above, pp. 178-181.

${ }^{87}$ Royal Society, Classified Papers (1660-1740), XIV (ii), 'Physick', 14: Jurin, 'An account of a remarkable instance of ye infection of ye small pox'.

${ }^{88}$ Creighton, op. cit., note 9 above, pp. $470-471$.

${ }^{8}$ SPCK, CN3/2, New England Letter Book, p. 57, Henry Newman to Dr Boylston, 28 June 1727. See also, Randolph Trumbach, The rise of the egalitarian family, New York, Academic Press, 1978, pp. 194-195.
} 


\section{Stewart}

Spaniards who had become increasingly wary of the contagion imported from Barbados.90

If quarantine might limit a smallpox epidemic, it was essentially a response to an outbreak. Inoculation was a prophylactic, if radical, intervention. Thus, by the end of the $1730 \mathrm{~s}$, as a result of severe outbreaks in connexion with the slave trade, inoculation began to revive. In 1738, a Guinea ship brought smallpox to Charleston resulting in 800 inoculations with over 3000 in the Barbados in the same year. ${ }^{91}$ By the last half of the century, it seems that inoculation was virtually routine in the West Indies plantations. Dr John Quier of Jamaica inoculated the slaves under his care, as ships' captains were reported to do upon their arrival in port. ${ }^{92}$ In testimony before the House of Commons Committee on the Slave Trade, it was revealed that inoculation had taken place on board a ship in 1777 with the loss of only seven out of $184 .^{93}$ The cutting of losses in the slave trade therefore provided positive proof of the efficacy of inoculation. While the motive may simply have been to secure profit in the trade, nonetheless the constancy of smallpox and the purpose of the slavers provided an opportunity to intervene in a way that was much more difficult in England, where the sensibilities and fears of individuals had to be taken into question. Thus, where Sloane's Newgate felons left off, and where the English aristocracy often feared to tread, the slaves who endured the middle passage provided the ironic and dramatic evidence of the success of a radical medical intervention.

\footnotetext{
${ }^{90}$ Palmer, op. cit., note 41 above, pp. 113-115. Clements Library, University of Michigan, Ann Arbor, Shelburne MSS. vol. 43, fols. 133-155, 14 April 1737; vol. 44, fols. 635-637, 10 June 1737; fols. 617-620, 9 June 1738.

${ }^{91}$ Miller, op. cit., note 8 above, pp. 135-136, 142; Creighton, op. cit., note 9 above, p. 489. Thomas Butcher, the Caracas agent, reported that Bridgetown was "seldom clear of the Small Pox". Clements Library, Shelburne MSS, vol. 44, f. 662.

${ }^{92}$ Sheridan, op. cit., note 34 above, pp. 292-293; Great Britain, House of Commons, Accounts and Papers, 1 April 1790, 29: 491-492.

${ }^{93}$ Ibid. p. 495 . Cf Herbert, op. cit., note 70 above, p. 546.
} 